\title{
A simple and reliable method for determination of optimum pH in coupled enzyme assays
}

Lee Bowman ${ }^{\ddagger 1}$, Rachael Motamed ${ }^{\ddagger}$, , Paul Lee ${ }^{\ddagger 2}$, Kadijah Aleem², Astha S Berawala1, Katherine L Hayden ${ }^{\star, 1}$, David J Bzik ${ }^{3}$ \& Debasish Chattopadhyay**,2

\section{ABSTRACT}

Determination of the optimum $\mathrm{pH}$ in a coupled enzyme assay poses significant challenges because altering the $\mathrm{pH}$ of the reaction mixture can affect the performance of both enzymes. Here, we demonstrate a simple and reliable method to determine the $\mathrm{pH}$ optimum for pyruvate kinase using the pyruvate kinase/lactate dehydrogenase coupled enzyme assay. This simple and reliable method can be broadly adapted to determine the $\mathrm{pH}$ optimum for various enzymes that are assayed using a coupled enzyme assay.

\section{METHOD SUMMARY}

This article describes a simple method to determine the optimum $\mathrm{pH}$ for the activity of one enzyme in a coupled enzyme assay. Decoupling of the two-step reaction is achieved by heat denaturing the enzyme catalyzing the first reaction at different $\mathrm{pHs}$ followed by the addition of the second enzyme at a constant $\mathrm{pH}$. The velocity of the second enzymatic reaction is determined by the concentration of the product produced in the first reaction, therefore, allowing the measurement of the optimum $\mathrm{pH}$ of the first enzyme by monitoring the rate of the second reaction.

The activity of many enzymes is

\section{KEYWORDS}

coupled enzyme assay - Cryptosporidium parvum $\cdot$ enzyme kinetics $\cdot$ lactate dehydrogenase $\cdot \mathrm{pH}$ optimization - Plasmodium falciparum • pyruvate kinase

${ }^{1}$ Department of Chemistry \& Physics, Birmingham-Southern College, Birmingham, AL 35254, USA; ${ }^{2}$ Department of Medicine, University of Alabama at Birmingham, Birmingham, AL 35294, USA; ${ }^{3}$ Department of Microbiology \& Immunology, Dartmouth Geisel School of Medicine, Lebanon, NH 03756, USA; *Author for correspondence: khayden@bsc.edu; **Author for correspondence: dchattop@uabmc.edu; ₹Authors contributed equally

BioTechniques 68: 200-203 (April 2020) 10.2144/btn-2019-0126 strongly influenced by the $\mathrm{pH}$ of the reaction milieu. Although some enzymes exhibit activity in a broad range of $\mathrm{pH}$ [1-3], many show maximal activity at a narrow $\mathrm{pH}$ range [4-6], referred to as the $\mathrm{pH}$ optimum. The $\mathrm{pH}$ optimum is a key parameter that must be determined accurately as enzymatic activity, behavior and/or assembly can often be governed by key ionizable amino acid residues [7-9]. A classic example of how key residues and proximity of residues can influence an enzyme's $\mathrm{pH}$ activity optimum is the HIV type 1 (HIV-1) protease. HIV-1 protease, an aspartyl protease, has a $\mathrm{pH}$ optimum that is significantly higher than their eukaryotic counterparts $[10,11]$. One study attributes this increased $\mathrm{pH}$ activity range to the absence of a key serine residue, found in most eukaryotic aspartyl proteases, which can form a hydrogen bond with the carboxyl oxygen of the key aspartic acid residues within the active site [12]

To properly characterize enzymatic properties, it is especially important to perform kinetic analyses of enzymes at the $\mathrm{pH}$ optimum. Therefore, the $\mathrm{pH}$ optimum is typically determined prior to detailed kinetic analyses [13]. Determining this parameter is usually straightforward and involves measuring reaction velocities under different $\mathrm{pH}$ conditions while keeping other parameters constant. However, evaluating the direct kinetics of many enzymatic reactions can be technically challenging. In certain cases, this difficulty is overcome by coupling two enzymatic reactions together such that the product(s) of the first reaction is a substrate(s) for another reaction, catalyzed by a second enzyme, which can be easily monitored [14-16]. Considering that the activities of both enzymes depend on the $\mathrm{pH}$ of the reaction medium in coupled enzyme assays, the two enzymatic reactions must be decoupled to measure the $\mathrm{pH}$ optimum of the enzyme of interest.
Owing to the technical challenges inherent with coupled assays as mentioned earlier, the $\mathrm{pH}$ optimum is often not experimentally determined for the primary enzyme of interest. For instance, pyruvate kinase (PyK), an evolutionarily conserved enzyme that is essential in the regulation of cellular metabolism in both eukaryotes and prokaryotes, has been extensively studied for over 60 years [17-22]. Although the $\mathrm{pH}$ optimum of some mammalian PyKs have been experimentally determined, to our knowledge, measurement of the $\mathrm{pH}$ optimum of many prokaryotic and parasitic PyKs, such as Cryptosporidium parvum PyK (CpPyK), has not been reported [23-26]. PyK catalyzes the irreversible transfer of a phosphate ion from phosphoenolpyruvate to ADP yielding pyruvic acid (PA) and ATP (Figure 1) and serves as a major regulator of the glycolytic flux [27-29]. In a typical activity assay, the PyK reaction is coupled to lactate dehydrogenase (LDH, reaction 2 in Figure 1), which catalyzes the $\mathrm{NADH}$-dependent reduction of PA to lactic acid. The $L D H$ reaction velocity can be easily measured using UV spectroscopy by monitoring the decrease in absorbance at $340 \mathrm{~nm}$ attributed to the oxidation of $\mathrm{NADH}$ to $\mathrm{NAD}^{+}[22,30]$.

Ideally, in a coupled enzyme assay, the enzyme of interest should determine the overall rate of the reaction such that the measured kinetic parameters are relevant to the enzyme of interest rather than the coupled enzyme. At low pyruvate concentration, the initial velocity $\left(v_{0}\right)$ for the LDH reaction is determined by the concentration of PA (Figure 1). Therefore, the rate of the $L D H$ reaction can be used as a measure of the PyK reaction velocity. The $\mathrm{pH}$ dependence of the PyK reaction therefore cannot directly be evaluated in the coupled enzyme assay considering that the $L D H$ reaction rate is also affected by $\mathrm{pH}[31,32]$. Although previous studies have reported methodology for deter- 


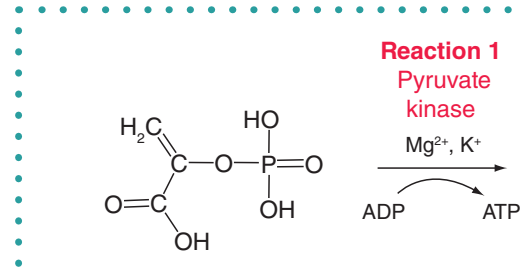

Phosphoenolpyruvate

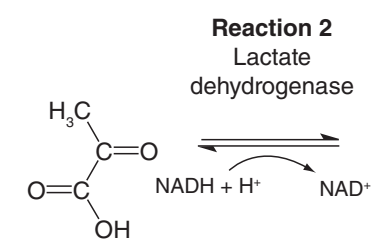

Pyruvate

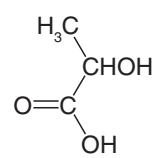

Lactate

Figure 1. The reaction schematic of the coupled pyruvate kinase and lactate dehydrogenase reaction to monitor pyruvate kinase kinetics. In the first reaction, pyruvate kinase (colored in red) irreversibly converts phosphoenolpyruvate to pyruvic acid (or pyruvate) while also converting ADP to ATP. In the second reaction, pyruvic acid is then reversibly converted to lactic acid using lactate dehydrogenase. During this step, NADH is oxidized to form NAD+ at the same rate as pyruvic acid production, allowing the analyst to follow the reaction rate of pyruvate kinase using UV-Vis spectroscopy by measuring the decrease in absorbance at $340 \mathrm{~nm}$ from NADH being consumed in reaction two $\left(e=6300 \mathrm{~cm}^{-1} \mathrm{M}^{-1}\right)$.

mining the $\mathrm{pH}$ optimum of PyK within this coupled assay $[23,24,26]$, we report an alternative, reliable and simple method for decoupling a coupled enzyme assay to determine the $\mathrm{pH}$ optimum of PyK using recombinant versions of $C p P y K$ [33] and Plasmodium falciparum LDH (PfLDH) [34]. The described method could potentially be adapted to determine the $\mathrm{pH}$ optimum of other PyKs and could be broadly applied to determine pH optima in other coupled enzyme assays.

\section{MATERIALS \& METHODS}

Recombinant $C p P y K$ was expressed and purified from Escherichia coli as detailed in Cook et al. [33]. Recombinant PfLDH was purified from $E$. coli using ammonium sulfate precipitation, affinity chromatography on Blue Sepharose resin (GE Healthcare), followed by size exclusion chromatography on Superdex 200 column (GE Healthcare; IL, USA.) [34]. Reagents used were from SigmaAldrich (MO, USA.).

The outline for a typical coupled assay to measure PyK activity is shown in Figure 1 in which PyK catalyzes the first reaction (1, conversion of phosphoenolpyruvate [PEP] to PA) and LDH catalyzes the second reaction (2, conversion of PA to lactic acid). Standard coupled assays are performed in $1.0 \mathrm{ml}$ of total reaction mixture containing $50-100 \mathrm{mM}$ Tris buffer (pH 7.5), $100 \mathrm{mM} \mathrm{KCl,} 5 \mathrm{mM} \mathrm{MgCl}_{2^{\prime}}$ $1 \mathrm{mM}$ PEP, $1 \mathrm{mM}$ ADP, $0.1 \mathrm{mM} \mathrm{NADH}$ and $1 \mu \mathrm{g}$ of $P f \mathrm{LDH}$. The reaction is initiated by adding $1 \mu \mathrm{g} \mathrm{CpPyK}$ and absorbance at $340 \mathrm{nM}$ is monitored in a temperature-controlled spectrophotometer (HP 8452A Diode Array; Hewlett Packard, CA, USA) at 25 or $30^{\circ} \mathrm{C}$. The optimum $\mathrm{pH}$ for $P f \mathrm{LDH}$ activity is in the range of $7.0-8.0$ [34].

To analyze the effect of $\mathrm{pH}$ on PyK activity, however, the two reactions must be decoupled. We decoupled the reactions by heat inactivating PyK at the end of reaction 1 and then used the heat-inactivated PyK reaction mixture as a source of $P A$ to drive reaction 2 followed by the addition of NADH and $P f L D H$. In control experiments, we determined $C p P y K$ enzyme is completely and irreversibly inactivated by incubation at $70^{\circ} \mathrm{C}$ for $5 \mathrm{~min}$ (data not shown). We also noted that the $C p P y K$ reaction was not affected by buffer concentration in the range of 10-100 mM. To ensure that the addition of the mixture after reaction 1 does not affect the $\mathrm{pH}$ of the $\mathrm{PfLDH}$ reaction, $C p P y K$ assays were performed in $10 \mathrm{mM}$ buffer. The $\mathrm{pH}$ of each mixture for reaction 1 was adjusted after addition of all reagents before adding CpPyK. Two different buffer systems were used: sodium acetate ( $\mathrm{pH}$ range: $4.0-6.5$ ) and Tris ( $\mathrm{pH}$ range 7.0-9.0).

The PyK reaction was carried out in $10 \mathrm{mM}$ buffer of various pHs containing $100 \mathrm{mM} \mathrm{KCl}$, $5 \mathrm{mM} \mathrm{MgCl}_{2}, 1 \mathrm{mM}$ ADP and $1 \mathrm{mM}$ PEP in a total volume of $1 \mathrm{ml}$ in Eppendorf tubes. Reaction 1 was initiated by adding $2.5 \mu \mathrm{g}$ of CpPyK to the tube and placed in $30^{\circ} \mathrm{C}$ water bath for $1 \mathrm{~min}$. For heat inactivation of $\mathrm{CpPyK}$, the tubes were then immediately placed into a $70^{\circ} \mathrm{C}$ water bath for $5 \mathrm{~min}$, followed by cooling on ice for $2 \mathrm{~min}$. The reaction mixtures were then subjected to centrifugation at $4500 \times$ $g$ for $5 \mathrm{~min}$. From each tube, $800 \mu \mathrm{l}$ of the supernatant were transferred to a $1-\mathrm{ml}$ quartz cuvette containing $200 \mu \mathrm{l}$ of $1 \mathrm{M}$ Tris buffer at $\mathrm{pH}$ 7.5. The second reaction was initiated by adding NADH (final concentration $0.1 \mathrm{mM}$ ) and $1 \mu \mathrm{g}$ of $P f \mathrm{LDH}$. The LDH reaction was then monitored for $1 \mathrm{~min}$ by following the absorbance at $340 \mathrm{~nm}$ at $25^{\circ} \mathrm{C}$. These experiments were repeated at least four times. To ensure that reaction 1 is the rate determining step of the coupled reaction, the amount of PfLDH to add in reaction 2 was determined by incrementally titrating increasing amounts of $P f \mathrm{LDH}$ in control experiments until the $v_{0}$ of reaction 2 no longer increased. The amount of $P f \mathrm{LDH}$ found within those experiments was then doubled to ensure that $P f L D H$ would remain in excess under all of the experimental conditions (data not shown).

The pH optimum of $C p$ PyK was determined by analyzing the rate of decrease in absorbance at $340 \mathrm{~nm}$ due to the consumption of $\mathrm{NADH}$ at each $\mathrm{pH}$ condition. Therefore, the $v_{o}$ of reaction 2 is calculated as molarity of $\mathrm{NAD}^{+}$formed over time (or NADH consumed) using the extinction coefficient of NADH $\left(e=6300 \mathrm{~cm}^{-1} \mathrm{M}^{-1}\right)$. The linear behavior of the $v_{0}$ of reaction 2 for longer than $1 \mathrm{~min}$ at each $\mathrm{pH}$ demonstrated that NADH was not limiting during reaction 2 (data not shown). Because the rate of the $L D H$ reaction (2) is dependent on the concentration of $\mathrm{PA}$ produced in reaction 1 , the $\mathrm{pH}$ of reaction 1 , which yielded highest $\mathrm{LDH}$ activity represents optimum $\mathrm{pH}$ for CpPyK activity.

An online step-by-step protocol of the assay described above with suggestions, reagents and equipment lists can be found at [41].

\section{RESULTS \& DISCUSSION}

In a set of control experiments, we determined that $C p$ PyK was completely and irreversibly inactivated by heating at $70^{\circ} \mathrm{C}$ for 3 min (data not shown). We also verified that the concentration of the buffer in the range of 10-100 mM did not affect CpPyK activity (data not shown). Moreover, addition of $10 \mathrm{mM}$ acetate or Tris buffer of different $\mathrm{pH}$ values to $1 \mathrm{M}$ Tris $\mathrm{HCl}, \mathrm{pH} 7.5$, in a ratio of 4:1 did not alter the $\mathrm{pH}$ of the latter buffer. Therefore, $800 \mu \mathrm{l}$ of the reaction mixture from $C p P y K$ reactions performed in $10 \mathrm{mM}$ acetate or in $10 \mathrm{mM}$ Tris $\mathrm{HCl}$ buffer after heat inactivation of the CpPyK enzyme were used to assay $\mathrm{LDH}$ activity at a constant $\mathrm{pH}$.

Because the $v_{0}$ of the $L D H$ reaction (2) is dependent on the concentration of PA, the rate of reaction 2 should be proportional to the $v_{0}$ of reaction 1 (PyK). Our analysis demonstrates that $C p P y K$ is enzymatically active in a broad range of $\mathrm{pHs}$ from 5.5 to 
8.0, with maximal activity at $\mathrm{pH} 7.0$ (Figure 2). CpPyK showed little activity at $\mathrm{pH} 4.0-5.0$ and increased more than threefold at pH 5.5. The activity decreased at $\mathrm{pH} 8.5$ and higher. These data demonstrate that the CpPyK is active over a broad $\mathrm{pH}$ range; however, the enzyme exhibits minimal activity at highly acidic conditions ( $\mathrm{pH} 5.0$ or below). Although many enzymes prefer a narrow range of $\mathrm{pH}$ for activity, others exhibit activity over a broad range of $\mathrm{pHs}$. Among the latter group are some parasitic enzymes [35], a number of small molecule kinases $[36,37]$ and PyKs from rabbit muscle PyK [23] and cyanobacterium Synechococcus PyK [38].

The determination of the optimum $\mathrm{pH}$ for an enzyme is important for the characterization of enzymatic properties and is often challenging to determine for enzymes within a coupled reaction [13]. Knowing whether the enzyme of interest has a narrow or broad range of $\mathrm{pH}$ activity is not only an important consideration for kinetic studies but could also be used to determine the potential chemical ruggedness or $\mathrm{pH}$ stability of an enzyme $[39,40]$. The method described here could potentially be used to accurately determine the $\mathrm{pH}$ optimum of other coupled enzyme assays or be modified to determine optimum parameters for the enzyme catalyzing the second reaction. One limitation of the proposed method is that any heat sensitive biochemical or chemical entity that may be necessary for the successful performance of the second reaction may be inactivated or damaged during the heat denaturation of the first enzyme. This method could also be expanded to determine and optimize other important chemical and physical properties of an enzyme within a coupled assay such as temperature, salt type and concentrations and/or other allosteric effectors.

We report a simple, cost-effective and reliable method for determining the $\mathrm{pH}$ optimum of an enzyme within a coupled assay by decoupling the two-step reaction with heat inactivation of the first enzyme. Additionally, the potential expansion of this method to include other parameters, such as optimum temperature, salts and allosteric effectors, could also be very beneficial. Accurate characterization of all enzymes within coupled assays is essential in the development of future coupled assays or

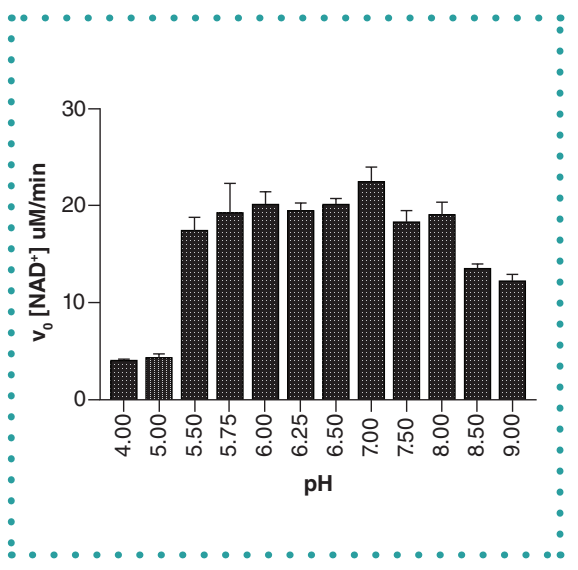

downstream applications that use coupled assays.

\section{SUPPLEMENTARY DATA}

To view the supplementary data that accompany this paper please visit the journal website at: www.future-science. com/doi/suppl/10.2144/btn-2019-0126

\section{AUTHOR CONTRIBUTIONS}

L Bowman, R Motamed and P Lee made equal and significant experiment contributions. $\mathrm{K}$ Aleem and AS Berawala also contributed to the experiments. KL Hayden, DJ Bzik and D Chattopadhyay made significant contributions to the preparation of the manuscript and guidance on the experiments. L Bowman also contributed to the preparation of the manuscript

\section{FINANCIAL \& COMPETING INTERESTS DISCLOSURE}

The initial studies on $C p P y K$ were conducted with funds from the American Foundation for AIDS Research (amfAR) (grant/award number 106493 35). The authors have no other relevant affiliations or financial involvement with any organization or entity with a financial interest in or financial conflict with the subject matter or materials discussed in the manuscript apart from those disclosed.

No writing assistance was utilized in the production of this manuscript.

\section{OPEN ACCESS}

This work is licensed under the AttributionNonCommercial-NoDerivatives 4.0 Unported License. To view a copy of this license, visit http://creativecommons.org/licenses/by-nc$\mathrm{nd} / 4.0 /$
Figure 2. The $\mathrm{v}_{\mathrm{o}}$ of Plasmodium falciparum lactate dehydrogenase as a response to pyruvate production by Cryptosporidium parvum pyruvate kinase at varying $\mathrm{pH}$ conditions. The data shown are the average initial reaction velocities (in $\mu \mathrm{M} / \mathrm{min}$ of $\mathrm{NAD}^{+}$) for the Plasmodium falciparum lactate dehydrogenase (PfLDH) reaction (2). Cryptosporidium parvum pyruvate kinase $(\mathrm{C} p \mathrm{PyK})$ reactions (1) were performed at various $\mathrm{pH}$ conditions ranging from 4.00 to 9.00 for $1 \mathrm{~min}$, heat-inactivated and $800 \mu$ l of reaction mixture was used for the $\mathrm{P} f \mathrm{LDH}$ reaction (total volume $1 \mathrm{ml}$ ) at $\mathrm{pH}$ 7.5. Error bars indicate standard error with a sample size of $n=4$ for each $\mathrm{pH}$ condition. $\mathrm{v}_{0}$ : Initial velocity.

\section{REFERENCES}

1. Yoong P, Schuch R, Nelson D, Fischetti VA. PlyPH, a bacteriolytic enzyme with a broad $\mathrm{pH}$ range of activity and lytic action against Bacillus anthracis. J. Bacteriol. 188(7), 2711-2714 (2006).

2. Sajedi RH, Naderi-Manesh $\mathrm{H}$, Khajeh $\mathrm{K}$ et al. A Ca-independent $\alpha$-amylase that is active and stable at low $\mathrm{pH}$ from the Bacillus sp. KR-8104. Enzyme Microb. Technol. 36(5-6), 666-671 (2005)

3. Bhunia B, Dutta D, Chaudhuri S. Extracellular alkaline protease from Bacillus licheniformis NCIM-2042: improv ing enzyme activity assay and characterization. Eng. Life Sci. 11(2), 207-215 (2011).

4. Grouneva I, Jakob T, Wilhelm C, Goss R. Influence of ascorbate and pH on the activity of the diatom xanthophyll cycle-enzyme diadinoxanthin de-epoxidase. Physiol. Plant. 126(2), 205-211 (2006).

5. Schnappauf G, Strater N, Lipscomb WN, Braus GH. A glutamate residue in the catalytic center of the yeast chorismate mutase restricts enzyme activity to acidic conditions. Proc. Natl Acad. Sci. USA 94(16), 8491-8496 (1997).

6. Dubnovitsky AP, Kapetaniou EG, Papageorgiou AC. Enzyme adaptation to alkaline $\mathrm{pH}$ : atomic resolution (1.08 A) structure of phosphoserine aminotransferase from Bacillus alcalophilus. Protein Sci. 14(1), 97-110 (2005).

7. Linebaugh BE, Sameni M, Day NA, Sloane BF, Keppler D. Exocytosis of active cathepsin B enzyme activity at pH 7.0, inhibition and molecular mass. Eur. J. Biochem. 264(1), 100-109 (1999).

8. Beiboer SH, Van Den Berg B, Dekker N, Cox RC, Verhei $H M$. Incorporation of an unnatural amino acid in the active site of porcine pancreatic phospholipase A2. Sub stitution of histidine by 1,2,4-triazole-3-alanine yields an stitution of histidine by 1,2,4-triazole-3-alanine yields an enzyme with high

9. Cronk JD, Endrizzi JA, Cronk MR, O'neill JW, Zhang KY. Crystal structure of $E$. coli beta-carbonic anhydrase, an enzyme with an unusual pH-dependent activity. Protein Sci. 10(5), 911-922 (2001).

10. Smith R, Brereton IM, Chai RY, Kent SB. Ionization states of the catalytic residues in HIV-1 protease. Nat. Struct. Biol. 3(11), 946-950 (1996).

11. Tang J, Wong RN. Evolution in the structure and function of aspartic proteases. J. Cell. Biochem. 33(1), 53-63 (1987).

12. Ido E, Han HP, Kezdy FJ, Tang J. Kinetic studies of human immunodeficiency virus type 1 protease and its active-site hydrogen bond mutant A28S. J. Biol. Chem. 266(36), 24359-24366 (1991).

13. Bisswanger H. Enzyme assays. Perspect. Sci. 1(1-6), 41-55 (2014).

14. Jones AJ, Hirst J. A spectrophotometric coupled enzyme assay to measure the activity of succinate dehydrogenase. Anal. Biochem. 442(1), 19-23 (2013).

15. Grsic-Rausch S, Rausch T. A coupled spectrophotometric enzyme assay for the determination of pectin methylesterase activity and its inhibition by proteinaceous inhibitors. Anal. Biochem. 333(1), 14-18 (2004).

16. Mcclure WR. A kinetic analysis of coupled enzyme assays. Biochemistry 8(7), 2782-2786 (1969).

17. Schormann N, Hayden KL, Lee P, Banerjee S, Chattopadhyay $\mathrm{D}$. An overview of structure, function, and regulation of pyruvate kinases. Protein Sci. 28(10), 1771-1784 (2019).

18. Carbonell JE, Feliu JE, Marco R, Sols A. Pyruvate 
kinase: classes of regulatory isoenzymes in mammalian tissues. Eur. J. Biochem. 37, 148-156 (1973).

19. Jurica MS, Mesecar A, Heath PJ, Shi W, Nowak T, Stoddard BL. The allosteric regulation of pyruvate kinase by fructose-1,6-bisphosphate. Structure 6, 195-210 (1998).

20. Oria-Hernandez J, Cabrera N, Perez-Montfort R, Ramirez-Silva L. Pyruvate kinase revisited: the activating effect of K+. J. Biol. Chem. 280(45), 37924-37929 (2005)

21. Anastasiou D, Yu Y, Israelsen WJ et al. Pyruvate kinase M2 activators promote tetramer formation and suppress tumorigenesis. Nat. Chem. Biol. 8(10), 839-847 (2012).

22. Bücher T, Pfleiderer G. "[66] Pyruvate kinase from muscle: pyruvate phosphokinase, pyruvic phosphoferase phosphopyruvate transphosphorylase, phosphate - transferring enzyme II, etc. Phosphoenolpyruvate+ ADP Pyruvate+ ATP.". Methods Enzymol. 435-440 (1955).

23. Ramirez-Silva L, De Gomez-Puyou MT, Gomez-Puyou A. Water-induced transitions in the $\mathrm{K}+$ requirements for the activity of pyruvate kinase entrapped in reverse micelles. Biochemistry 32(20), 5332-5338 (1993).

24. Dougherty TM, Cleland WW. pH studies on the chemical mechanism of rabbit muscle pyruvate kinase. 2. Physiological substrates and phosphoenol-alpha-ketobutyrate. Biochemistry 24(21), 5875-5880 (1985).

25. Fenton $\mathrm{AW}$, Hutchinson $\mathrm{M}$. The $\mathrm{pH}$ dependence of the allosteric response of human liver pyruvate kinase to fructose-1,6-bisphosphate, ATP, and alanine. Arch Biochem. Biophys. 484(1), 16-23 (2009).

26. Dougherty TM, Cleland WW. pH studies on the chemical mechanism of rabbit muscle pyruvate kinase. 1. Alternate substrates oxalacetate, glycolate, hydroxylamine, and fluoride. Biochemistry 24(21), 5870-5875 (1985).

27. Fothergill-Gilmore LA, Michels PA. Evolution of glycolysis. Prog. Biophys. Mol. Biol. 59(2), 105-235 (1993).

28. Lehninger AL. Principles of Biochemistry (5th Edition). WH Freeman, NY, USA (2008)

29. Berg JM, Tymoczko JL, Stryer L. Section 16.2 The Glycolytic Pathway. NY, USA (2002).

30. Kiianitsa K, Solinger JA, Heyer W-D. NADH-coupled microplate photometric assay for kinetic studies of
ATP-hydrolyzing enzymes with low and high specific ATP-hydrolyzing enzymes with low and high specific
activities. Anal. Biochem. 321(2), 266-271 (2003).

31. Yancey PH, Somero GN. Temperature dependence of intracellular $\mathrm{pH}$ : its role in the conservation of pyruvate apparentK $m$ values of vertebrate lactate dehydrogenases. J. Comp. Physiol., B 125(2), 129-134 (1978).

32. Brown WM, Yowell CA, Hoard A et al. Comparative structural analysis and kinetic properties of lactate dehydrogenases from the four species of human malarial parasites. Biochemistry 43(20), 6219-6229 (2004).

33. Cook WJ, Senkovich O, Aleem K, Chattopadhyay D. Crystal structure of Cryptosporidium parvum pyruvate kinase. PLOS ONE 7(10), e46875 (2012).

34. Shoemark DK, Cliff MJ, Sessions RB, Clarke AR Enzymatic properties of the lactate dehydrogenase
enzyme from Plasmodium falciparum. FEBS J. 274(11), 2738-2748 (2007)

35. Lowther J, Robinson MW, Donnelly SM et al. The importance of $\mathrm{pH}$ in regulating the function of the Fasciola hepatica cathepsin L1 cysteine protease. PLoS Negl. Trop. Dis. 3(1), e369 (2009).

36. Ramachandran CK, Shah SN. Studies on mevalonate kinase, phosphomevalonate kinase and pyrophospho- mevalonate decarboxylase in developing rat brain. $J$. Neurochem. 28(4), 751-757 (1977).

37. Simon LM, Szelei J, Szajáni B, Boross L. Immobilization of pig muscle 3-phosphoglycerate kinase. Enzyme Microb. Technol. 7(7), 357-360 (1985).

38. Knowles VL, Smith CS, Smith CR, Plaxton WC. Structural and regulatory properties of pyruvate kinase from the Cyanobacterium synechococcus PCC 6301. J. Biol. the Cyanobacterium synechococcus PCC
Chem. 276(24), 20966-20972 (2001).

39. Eijsink VG, Bjork A, Gaseidnes S et al. Rational engineering of enzyme stability. J. Biotechnol. 113(1-3), 105-120 (2004).

40. Mohamed Ahmed IA, Babiker EE, Mori N. pH stability and influence of salts on activity of a milk-clotting enzyme from Solanum dubium seeds and its enzymatic action on bovine caseins. LWT-Food Sci. Technol. 43(5), 759-764 (2010)

41. Bowman $L$, Motamed R, Lee $P$ et al. A simple and reliable method for determination of optimum $\mathrm{pH}$ in coupled enzyme assays. protocols.io. https://protocols. io/view/a-simple-and-reliable-method-for-determination-of-bb9jir4n 